\title{
Cacao Diseases: A Global Perspective from an Industry Point of View
}

\author{
Prakash K. Hebbar
}

Mars Inc./USDA-ARS, Sustainable Perennial Crops Laboratory, Building 011A, Room 328, Beltsville, MD 20705.

\begin{abstract}
Hebbar, P. K. 2007. Cacao diseases: A global perspective from an industry point of view. Phytopathology 97:1658-1663.

Diseases of cacao, Theobroma cacao, account for losses of more than $30 \%$ of the potential crop. These losses have caused a steady decline in production and a reduction in bean quality in almost all the cacaoproducing areas in the world, especially in small-holder farms in Latin America and West Africa. The most significant diseases are witches' broom, caused by Moniliophthora perniciosa, which occurs mainly in South America; frosty pod rot, caused by $M$. roreri, which occurs mainly in Central and northern South America; and black pod disease, caused by several species of Phytophthora, which are distributed throughout the

tropics. In view of the threat that these diseases pose to the sustainability of the cacao crop, Mars Inc. and their industry partners have funded collaborative research involving cacao research institutes and governmental and nongovernmental agencies. The objective of this global initiative is to develop short- to medium-term, low-cost, environmentally friendly disease-management strategies until disease tolerant varieties are widely available. These include good farming practices, biological control and the rational or minimal use of chemicals that could be used for integrated pest management (IPM). Farmer field schools are used to get these technologies to growers. This paper describes some of the key collaborative partners and projects that are underway in South America and West Africa.
\end{abstract}

Theobroma cacao L., the source of cocoa beans used to make chocolate, is a tropical, low-input, perennial tree crop grown by small-holder farmers. Unfortunately, the crop suffers from a number of devastating diseases. Among the most important are: witches' broom caused by Moniliophthora perniciosa (=Crinipellis perniciosa), frosty pod caused by M. roreri, and black pod disease caused by various species of Phytophthora $(1,15,16)$. In addition, insect pests such as the cocoa pod borer and mirids are also major problems. Losses to the crop from various pests and diseases worldwide are very significant and the potential loss in production is currently estimated at $\approx 1.0$ million tons (Fig. 1).

A total of 3.2 million tons of cacao is produced throughout the humid tropics, and almost 65 to $70 \%$ of this crop is produced in a relatively small region of West Africa comprised of Ivory Coast (40\%), Ghana (15\%), Nigeria (5\%) and Cameroon (5\%). The remaining $30 \%$ comes from Indonesia (12\%), Latin America (8\%) and rest from smaller producers in the tropics $(10 \%)$. Diseases of cacao can account for losses of more than $30 \%$ of the potential crop and this, along with old, less productive trees, has caused a steady decline in global production. A good example of the devastating impact of an invasive fungal disease is witches' broom disease which reduced production in Brazil by 75\%, (from 400,000 to 100,000 tons) in only 10 years (25). Small-holder production in Central and northern South America has been devastated by frosty pod rot, and production in West Africa is threatened by the highly virulent black pod pathogen, $P$. megakarya $(10,22,27)$. Accidental introduction of exotic diseases is perceived as a potential threat $(9,26,27)$.

Corresponding author: P. K. Hebbar; E-mail address: Prakash.Hebbar@effem.com

* The $\boldsymbol{e}$-Xtra logo stands for "electronic extra" and indicates that the online version contains supplemental material not included in the print edition. Figure 2 appears in color online.

doi:10.1094/PHYTO-97-12-1658

(C) 2007 The American Phytopathological Society
Although much research has been published over the past few decades on these diseases, sustainable management strategies that are applicable to small-holder farms are still lacking in most producing countries. Cacao is often described as an "orphan crop" because production is not backed with adequate technical infrastructure in producing countries. Most cacao-producing regions in the world lack the two major pillars of modern agriculture, a wellfunded extension service and readily available, disease-tolerant cultivars or clones. Cacao is certainly not alone in dealing with this problem in the less developed countries. In general, phytosanitation and sometimes the use of expensive fungicides are the only available disease-management tools. But chemical fungicides are often used too late or with poor application methods or wrong timing. In badly maintained cacao farms, trees may be taller than 5 to 10 meters, which is too high for phytosanitation and chemical application; thus, infected host tissues are a constant source of inoculum that make either method of intervention futile.

Average size of cacao farms ranges from 1 ha in Asia to almost 20 ha in Latin America, and somewhere in between in West Africa. Farmers often depend on family to work on farms, rather than hired labor. Fluctuating and sometimes low prices for cocoa beans is a major factor that affects fertilizer, chemical, and labor inputs.

Cacao production can be viewed as an 18th century agriculture system that provides a product for a 21 st century industry. Until disease-tolerant cultivars are readily available and adequate extension services are provided, a low-input IPM strategy disseminated through farmer field school training is seen as a short- to mediumterm solution to the current challenges in pest management. An expert forecast on future progress and research priorities and policy for cocoa crop protection conducted in 1997 has indicated that resistance breeding and integrated control is likely to be more successful than biological control or phytosanitation alone (16). However, the same survey indicated that at least a quarter of the experts expect some progress in biocontrol application for managing black pod disease and the cocoa pod borer pest in the near future (16). Research and application of biological control fungus 
Trichoderma to enhance disease management, a normally expensive option in developed countries, along with the rational use of chemicals, will be discussed in this paper (16). This is the first large-scale attempt to include biological control, hitherto neglected, as a part of the IPM strategy.

Development of public-private partnership in integrated pest management of cacao diseases. Mars Incorporated (Inc.) is a global corporation whose products are consumed in over 100 countries. Mars Inc. responded to the above disease problems with the proactive Cocoa Sustainability Program. It is a globally distributed partnership engaged in developing research networks, and funding or co-funding projects on farmer training and extension. The program works closely with donor agencies with a goal of better management and formulation of in-country programs that address not only disease problems, but also productivity, quality, the environment, agro-forestry, and social development. This has helped create synergies with partners throughout the cacao sector, including public entities such as agricultural departments and aid agencies to name a few, that operate within a collaborative program. The global research linkages now include industry partners, such as the World Cocoa Foundation (WCF), in collaboration with the U.S. Department of Agriculture-Agricultural Research Service (USDA-ARS), the U.S. Agency for Inter-

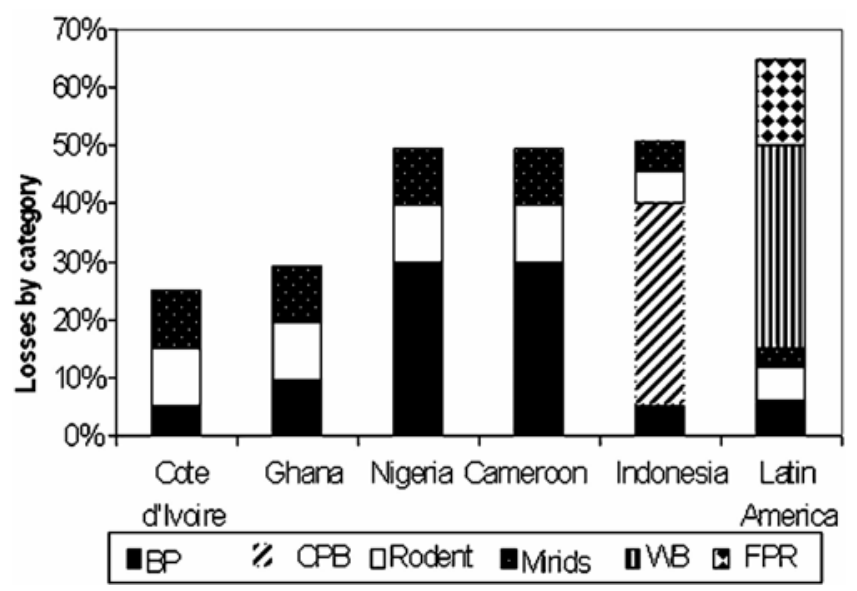

Fig. 1. Production losses in major cacao-growing countries due to pests and diseases and rodent damage: $\mathrm{BP}=$ black pod, $\mathrm{CPB}=$ cocoa pod borer, $\mathrm{WB}=$ witches' broom, and FPR = frosty pod rot. (Courtesy P. van Grinsven, Mars, Inc.) national Development (USAID), universities, National Research Centers in producing countries, cacao research institutes, and nongovernment organizations (NGOs).

The dramatic decline of cacao production in Brazil due to witches' broom was a warning to the industry that it has to be more proactive and that efforts should be made to address pest and disease problems. This was also a clear indication that efforts should be made to prevent this or other exotic diseases and pests from moving into West Africa, the largest cacao producing region in the world; or Southeast Asia, a producing region of increasing importance. Moreover, there was a perceived need to enhance the technical response of, and identify collaborative goals and capabilities in, cacao-producing countries.

The USDA-ARS currently has two large cacao research programs, one on cacao molecular characterization and breeding based at USDA-ARS-Miami, Florida and one on biological control and IPM based at USDA-ARS in Beltsville, Maryland. These programs were instituted by USDA-ARS with Mars Inc. as Cooperative Research and Development Agreements (CRADAs). Currently, the ARS programs receive not only Mars Inc. financial support, but also Mars Inc. scientists work closely with ARS scientists at each location.

IPM of cacao diseases. A 5-year program to develop environmentally sustainable methods for cacao disease management was instituted at USDA-ARS, Beltsville, Maryland in 1999 and extended in 2004 for another 5 years (2004 to 2009) as the basis for a global IPM program (http://www.dropdata.org/cocoa/index.htm). The objectives of the program are to (i) conduct basic research on cacao pests, pathogens, and biological control agents (ii) conduct applied research by setting up small scale to full IPM field trials in Asia, Africa, and Latin America; which includes rational use of chemicals (iii) develop tools to monitor pests, pathogens, and their spread; and (iv) find mechanisms for technology transfer to the cacao growers. The above, in addition to improved agronomy and better development and availability of disease resistant trees, are seen as integral parts of the process. Partners in the IPM research are listed in Table 1.

Integration of biological control into IPM of witches' broom disease in Brazil. Various efforts were made to eradicate witches' broom after it moved into the state of Bahia in the late 1980s $(20,24)$. Unfortunately, the cost of intervention with phyto-sanitation and spraying copper-based fungicides was not sustainable due to the rapid spread of the disease. Today, the price of copper based fungicides have doubled and newer chemistries developed

TABLE 1. Cooperative partners with the U.S. Department of Agriculture-Agricultural Research Service (USDA-ARS/Mars Inc.) program on cacao integrated pest management

\begin{tabular}{|c|c|}
\hline Countries & Organizations \\
\hline \multicolumn{2}{|c|}{ Producing countries } \\
\hline Brazil & Comissaõ Executiva do Plano da Lavoura Cacaueira (CEPLAC) (www.ceplac.gov.br), and Mars-Almirante Cacau Farm \\
\hline Cameroon & $\begin{array}{l}\text { Institut de Recherche Agricole pour le Developpement (IRAD) (www.irad-cameroon.org), Institute for International Tropical } \\
\text { Agriculture (IITA) (www.iita.org), and Sustainable Tree Crops Program (STCP) (www.treecrops.org) }\end{array}$ \\
\hline Colombia & Corporacion Colombiana de Investigacion Agropecuaria (CORPOICA) \\
\hline Costa Rica & Centro Agronomico Tropical de Investigacion y Ensenanza (CATIE) \\
\hline Ecuador & $\begin{array}{l}\text { Instituto Nacional Autonomo de Investigaciones Agropecuarias (INIAP) (www.iniap-ecuador.gov.ec/eepichilingue/index.php), and } \\
\text { Non-Governmental Organizations (NGOs) }\end{array}$ \\
\hline Nigeria & Cocoa Research Institute of Nigeria (CRIN) \\
\hline Panama & $\begin{array}{l}\text { Smithsonian Tropical Research Institute (STRI), and Agricultural Cooperative Development International-Volunteers in Overseas } \\
\text { Assistance (ACDI-VOCA) (www.acdivoca.org) }\end{array}$ \\
\hline Peru & Instituto de Cultivos Tropicales (ICT), and Sevicio Nacional de Sanidad Agraria (SENASA) \\
\hline \multicolumn{2}{|c|}{ Consuming countries } \\
\hline France & $\begin{array}{l}\text { Centre de Cooperation Internationale en Recherche Agronomique (CIRAD) (www.cirad.france), and USDA-ARS, USDA European } \\
\text { Biological Control Laboratory (EBCL) }\end{array}$ \\
\hline
\end{tabular}


for high-value crops are too expensive to be used on cacao (23; R. Bateman, IPARC, Imperial College, UK, personal communication). However, the efforts in Bahia in the 1990's failed largely due to complex issues such as low cacao prices, the rapid spread of the pathogen, lack of resistance in local materials, optimal climatic conditions for disease development, and the eradication policy that made farmers reluctant to inform authorities about the presence of the disease (24).

The discovery of a saprophytic natural biological control agent, Trichoderma stromaticum in Para State has given new impetus to the integrated management of witches' broom with potential for a nonchemical intervention $(3,28,30)$. T. stromaticum is a newly discovered species found in association with the brooms and infected pods. The fungus has mycoparasitic activity against $M$. pernici$o s a$, possibly due to production of hydrolytic enzymes and antifungal metabolites $(2,3,4,11,32)$. It is also compatible with copperbased fungicide, copper hydroxide. An interesting observation was that basidiocarps, essential for completing the life-cycle of M. perniciosa, are not produced on host tissue parasitized with $T$. stromaticum, thus interrupting the disease cycle. We now refer to this mode of action as biological pruning or biological phytosanitation. Thus the use of this biological control agent could potentially allow farmers to eliminate expensive phytosanitary pruning of brooms, a step that is presently required for management of this disease. Initial small field trials with T. stromaticum had shown not only reduced broom formation but also improve pod production (3).

Because the expense and scale of traditional phytosanitation impede its wide adoption and effective implementation, other tools are needed to combat witches' broom. Breeding for resistance to this disease at CEPLAC (Comissao Executiva do Plano da Lavoura Cacaueria) has slowly but steadily improved production. Farmers are now cloning resistant materials via grafting, and rooted cuttings of resistant planting material which is available, at a nominal cost, from Biofabrica, a Bahia government-supported nursery (http://www.biofabricadecacau.com.br). Since 1995, about 150,000 ha of the 500,000 ha in production $(30 \%)$ has been replanted or trees grafted with tolerant stock. Details of cacaobreeding projects are discussed further in the symposium paper presented by Schnell et al. (35).

Thanks to an international collaborative network, CEPLAC screens material for resistance to witches' broom, produces and distributes resistant materials through Biofabrica, and also produces $T$. stromaticum as a semi-commercial product under the brand name Tricovab that is sold to growers at a subsidized or modest cost $(\approx \$ 2.50 / 40 \mathrm{~g}$ packet/ha application) $(28)$. The international network has worked closely with CEPLAC to modernize the Tricovab, pilot production facility and to improve formulation and application methodologies (5). Mycoharvestor technology for separating fungal spores from the rice substrate (http://www.dropdata.org/mycoharvester/mh3.pdf) was transferred to CEPLAC with joint Mars-USDA-ARS funding and technical assistance from CABI-BioScience and Imperial College, UK. Now we have to wait and see whether this biocontrol technology can be advanced to a commercial level. CEPLAC currently is not able to provide adequate quantities of the material to the farmers. Difficulties in the commercial development of Tricovab include complicated registration procedures in Brazil and a lack of commercial interest to produce the biocontrol agent. However, discussions are underway with private companies about producing biological agents in Brazil.

However, basic research such as studies on the epidemiology of T. stromaticum, undertaken in Brazil with funding from USDAARS and Mars, has revealed important information on the spread and persistence of this biocontrol agent (12). Based on both classical taxonomy and molecular methods (AFLP-amplified fragment length polymorphism), it is now clear that there are two groups of the fungus in Bahia, one introduced from the Amazon region of Brazil (G II) by CEPLAC in 1999, and the other naturally occurring, and of unknown origin $(\mathrm{G} \mathrm{I})(4,7,11,12)$. The naturally occurring strains, isolated from areas that were not sprayed previously with the (G II) strain from the Amazon region, are genetically diverse, can reproduce sexually, and colonize brooms more efficiently under higher temperatures $(7,12,17)$. G II may not be unique to Bahia, as a strain with a similar molecular profile has now been discovered in Colombia (12).

T. stromaticum, but particularly the naturally occurring G I group, has all the characteristics of a classical biocontrol agent (13). The fungus can be found more frequently in close association with the witches' broom infected tissues in the cacao farms in Bahia now, than when this research was initiated in 1999 (12). The current working hypothesis is that this mycoparasite may have coevolved with its host $(M$. perniciosa $)(12,13)$. It is naturally spreading in the cacao-growing region of Bahia. However, time will tell how efficiently it reduces disease pressure and whether there will be a need for repeated applications of the agent. The advantage would be fewer dollars spent on the material and labor for spray application. Unfortunately, the G I strain, unlike the G II strain, is fastidious and does not grow well when rice grains are used as a substrate and, therefore, the fungus cannot be mass produced with existing technologies. Research underway at the Almirante Mars Center in Bahia has shown that G I strains can grow well in a broom extract medium (A. Pomella, personal communication).

Results from a multi-year field trial conducted in Bahia jointly with CEPLAC, with the G II strain, is very promising: Sprays of Group II strain alternated with copper fungicides, increased flowering, pod production, and reduced flower cushion brooms (P. Hebbar, personal observations) (http://www.dropdata.org/cocoa/ cocoa_biological.htm). The long term objective is to develop an IPM strategy, which includes, fungicide application and biocontrol sprays, which is easy to implement and economically sustainable for cacao farmers.

Development of IPM for frosty pod rot in Ecuador. The fineflavored Nacional cultivars in Ecuador are highly susceptible to frosty pod and witches' broom, and losses can range from $30 \%$ to $80 \%$ (14). Although recommendations for the integrated management of frosty pod rot exist, they have been adopted by few farmers (14). This has resulted in a loss of quality, due to mixing of healthy and fungus-infested beans.

The current cacao growing conditions in Ecuador render the application of both cultural practices and fungicide application difficult, especially where trees are higher than 5 to $6 \mathrm{~m}$ (Fig. 2). Reduction of tree height can reduce diseases significantly, and double yields from a current $300 \mathrm{~kg} / \mathrm{ha}$ to at least $600 \mathrm{~kg} / \mathrm{ha}$ (C. Suarez, personal communication). Fungicide application is rare, mainly due to lack of financial resources. The exporters and small traders (i.e., farmer middlemen) play an important role in the supply chain of the cocoa beans and determine the price paid for beans. This price is often 30 to $40 \%$ lower than the market price $(\approx \$ 1.50 / \mathrm{kg}$ ), which provides little incentive for farmers to try to produce more or higher quality beans. This has resulted in Nacional farms being neglected; and today they are often no- or lowinput farms. However, beginning from late 2006 until now (June $2007)$, the price for Ecuadorian cocoa has increased substantially $(\approx \$ 2.0$ per kilogram) resulting in better prices paid to the farmers. This has at least temporarily resulted in more activities in the small farms.

For several years, a USDA-ARS and Industry (Mars Inc. and World Cocoa foundation)-funded project on breeding for resistance, biocontrol, IPM, and quality improvement has been conducted in Ecuador in collaboration with the national cacao research institute, INIAP (Instituto Nacional Autonomo de Investigaciones Agropecuarias), in Pichilingue. Recently, a biocontrol facility was established to promote research on biocontrol and its integration into the current IPM strategy. Probable coevolved mycoparasites 
of both $M$. perniciosa (T. stromaticum) and M. roreri (T. ovalisporum, T. koningiopsis, and T. paucisporum) have been discovered and tested in pilot trials in farmer fields in Peru, Ecuador, and Costa Rica $(18,19,31)$. The above biocontrol agents reduce sporulation of the pathogens on pods, improve pod set, and persist in flower cushions for over 4 months (C. Suarez, personal communication).

Field trials in Costa Rica have shown that copper fungicides, if applied and timed properly, can protect pods against frosty pod rot and increase yields. When applied with mist-blowers, they were more effective than certain systemic fungicides (6). However, fungicide sprays may not be effective in reducing the release of spores by the pathogen. The reduction of pod infection with biocontrol agents is being evaluated by INIAP, in combination with copper (copper oxide and copper hydroxide), and newer, environmentally compatible fungicides such as azoxystrobins and chlorothalonil ACDI-VOCA (Agricultural Cooperatives Development International/Volunteers in Overseas Cooperative Assistance) is also engaged in farmer field school programs, and over 14,000 farmers have been trained in simple disease detection, phytosanitation, and cloning techniques. Currently, larger multilocation trials are underway in Ecuador in collaboration with ACDI-VOCA in farmer fields to test some of the IPM methods described above. Plants developed at INIAP that are high yielding and tolerant to frosty pod are also distributed to the farmers through clonal gardens.

Development of IPM for black pod disease in Cameroon and West Africa. Black pod management is difficult in high rainfall regions because Phytophthora spp. are favored in these environments. This, along with poor phytosanitation in small farms, results in severe losses in West Africa (21). Fungicide sprays applied on pods can reduce black pod and copper based contact fungicides, and the semi-systemic fungicide metalaxyl (Ridomil) are widely used. However, farmers either use them minimally, cannot afford them, or apply them too late. In addition, tall trees render the application of fungicides difficult using the standard knap-sack sprayer used by small farmers (24). Heavy rainfall also reduces the efficiency of fungicides, especially contact copperbased fungicides. Cacao cultivars tolerant to black pod are not yet available for large-scale distribution in Cameroon. Attempts are being made to evaluate and propagate farmer selections and selections made by breeders at IRAD, Cameroon, and CRIG, Ghana, that show tolerance to black pod under a new international initiative funded by CFC (Common Funds for Commodities). Therefore, until tolerant clones are available to the farmers in a large scale, alternative control strategies such as biocontrol, integrated into an IPM strategy, are attractive for low-input African farming systems. In Africa, if quality control measures are followed, low labor and locally available substrates may make biocontrol more attractive, cost-wise, than in more developed countries. Until then, chemical control is the only method available in West Africa.

A project was established at the Cacao Research Center of IRAD in Yaoundee, Cameroon, to investigate novel IPM strategies, including biocontrol, rational use of chemicals, and technology transfer through farmer field schools. Funding was received from the IITA, STCP, USDA-ARS/Beltsville and EBCL, USAID, and Mars Inc. Other collaborators included CIRAD and IPARC. This public-private partnership is in its third year, and has resulted in the establishment of a Regional Biological Control Laboratory, an improved formulation facility, capacity building of local scientists, and frequent scientific exchanges. Biocontrol agents are being tested in field trials, with parallel advanced research at USDA, CIRAD and Imperial College (8).

The biological control agent T. asperellum (29), a mycoparasite discovered by scientists at IRAD, has shown promise in management of black pod caused by P. megakarya (34). In three climatic zones with different disease pressures, strains of $T$. asperellum increased flowering and pod-set when sprayed on cacao trees.
Although, not as effective as chemical fungicides for pod protection, T. asperellum persists in high numbers and reduces Phytophthora infection in flower cushions. Field trials were initiated in 2006 to evaluate combinations of copper-tolerant T. asperellum and copper hydroxide fungicide for pod protection. A next logical step would be to involve private enterprise for registration and commercialization of the biocontrol agent

Demonstrations of the benefits of biocontrol agents and their proper application are essential. Though the breeding program is still years away from providing disease-tolerant cultivars and there is an urgent need to find low-cost methods to manage black pod, large-scale use of biocontrol agents by small-scale farmers in Cameroon will not be achieved unless they are convinced of their efficacy, and they are available at a reasonable price.

\section{DISCUSSION}

The experience gained from these public-private partnerships, although in their infancy, has been beneficial for both the chocolate industry and the national research centers in cacao-growing countries. On-site presence and networking, backed by broad technical capabilities of both the public and private entities, has allowed for rapid implementation of project results. This should help the flow of research and IPM technology to producers and

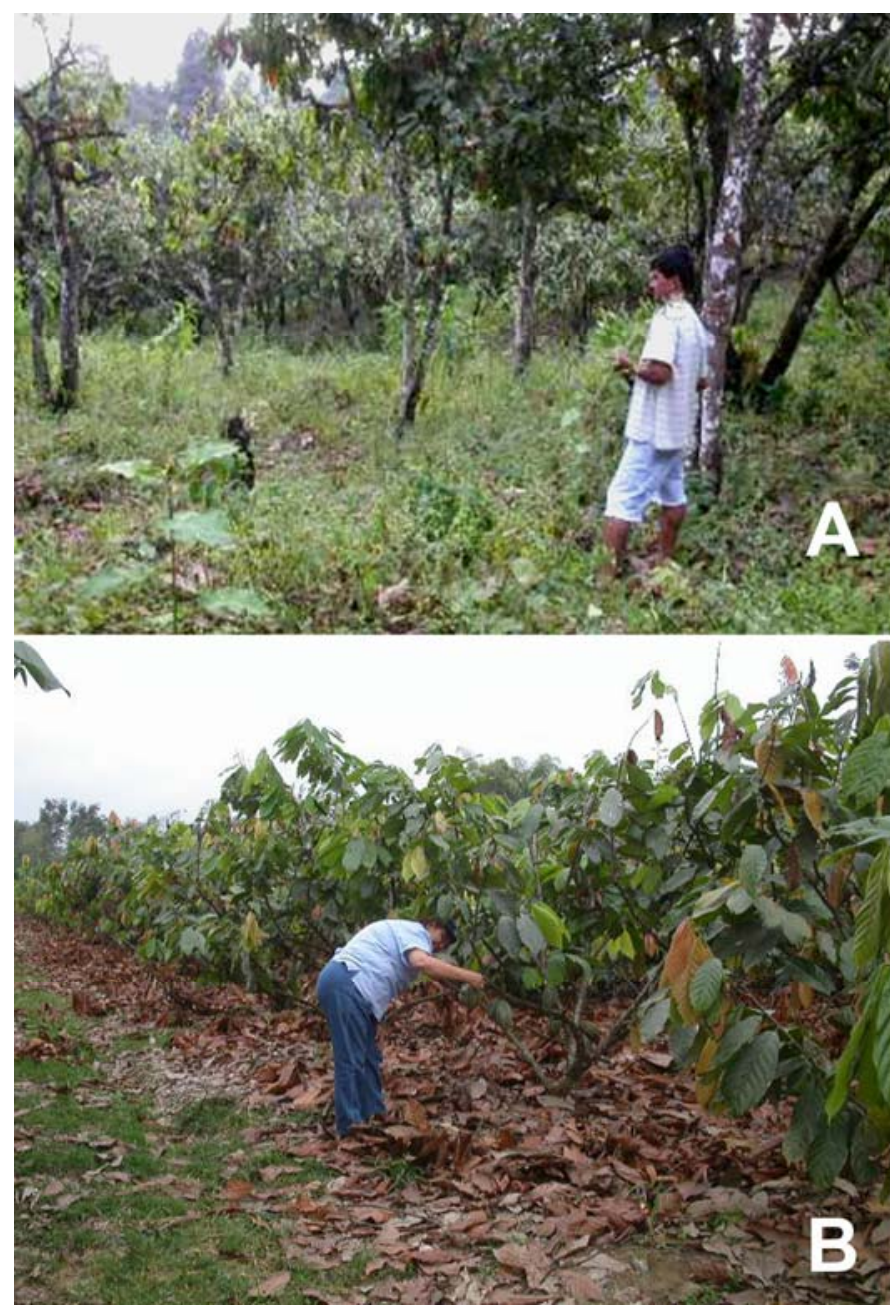

Fig. 2. Cacao plantation management has a profound impact on diseases and the ease with which control measures are applied. In these examples from Ecuador, A, sanitation (removal of diseased pods) is not practiced in a poorly managed farm and tree height makes application of biological and chemical treatments difficult and less effective than is possible in $\mathbf{B}$, a well-managed farm where canopy management and pod sanitation are utilized. (Courtesy C. Suarez, INIAP) 
farmers through cooperative programs with National Research Centers and nongovernmental organizations. We now have a better knowledge of cacao pathogens, disease epidemiology, integrated pest management, the potential for low cost biological control and the rational or reduced use of chemicals. This paper has not gone into detail on the use of chemical for cacao disease control, as their use is minimal or sporadic in Latin America and it is only slightly greater in West Africa. In addition, there has been no major breakthrough in application of new chemistries, nor widespread use by small farmers.

Pilot field trials have been set up in Brazil, Cameroon, Costa Rica, Peru, Panama, and Ecuador. Training of numerous $(>50)$ scientific personnel from cacao-producing countries has occurred over the past 7 to 8 years through funding of short-term fellowships by USDA-FAS, WCF, Mars Inc., European Trade Organizations, USDA-ARS; as well as longer-term Ph.D. programs ( $>10)$ at Universities in the United Kingdom, the United States, Australia, and France, in addition to the programs in the cacao producing countries. The cacao IPM programs are now tied closely to major cacao projects, research organizations, universities, nongovernmental organizations, and USAID. The cofunding of projects has helped sustain major programs currently in place in cacao-producing countries.

The chocolate industry, and especially Mars Inc., does not foresee a quick solution to these disease problems, but it is confident that small-scale farmers in the producing countries can obtain improved yields with better disease-management practices. The industry expects that these research programs will result in better quality and a sustainable supply of cacao beans being exported from the producing countries.

The private sector and nonindustry partnership is mutually beneficial, but will require continual contact, renewal, refinement, and search for synergies. Personnel from both private and public sectors should utilize networking and "outside-the-box" thinking skills and ideas to ensure a long-term supply of quality cacao beans that are produced in a manner that is of environmental, social and economic benefit for small-scale farmers. IPM is key to a longterm, sustainable cacao cultivation that will result in an adequate supply of cacao, enhance quality, improve small-farmer income, address safety issues, and alleviate environmental concerns.

\section{ACKNOWLEDGMENTS}

The author thanks R. Lumsden, Research Advisor, World Cocoa Foundation for reviewing the paper, and P. van Grinsven, Field Research Manager, Mars. Inc., for providing valuable information on cacao pests and diseases.

\section{LITERATURE CITED}

1. Aime, M. C., and Phillips-Mora, W. 2005. The casual agents of witches' broom and frosty pod rot of cacao (chocolate, Theobroma cacao) form a new lineage of Marasmiaceae. Mycologia 97:1012-1022.

2. Aneja, M., Gianfagna, T. J., and Hebbar, K. P. 2005. Trichoderma harzianum produces nonanoic acid, an inhibitor of spore germination and mycelial growth of two cacao pathogens. Physiol. Mol. Plant Pathol. 67:304-307.

3. Bastos, C. N. 1996. Potential of Trichoderma viride for control of cocoa witches' broom (Crinipellis perniciosa). Fitopatol. Brasil 21:509-512.

4. Bastos, C. N. 1996. Mycoparasitic nature of the antagonism between Trichoderma viride and Crinipellis perniciosa. Fitopatol. Brasil. 21:5054.

5. Bateman, R. P. 2004. Constraints and enabling technologies for mycopesticide development. Outl. Pest Manage 1:64-69.

6. Bateman, R. P., Hidalgo, E., Garcia, J., Arroyo, C., Ten Hoopen, G. M., Andonijah, V., and Krauss, U. 2005. Application of chemical and biological agents for the management of frosty pod rot (Moniliophthora roreri) in Costa Rican cocoa (Theobroma cacao). Ann. Appl. Biol. 147:129-138.

7. Bezerra, J. L., Costa, J. C. B., Bastos, C. N., and Faleiro, F. G. 2003. Hypocrea stromatica sp. nov. teleomorfo de Trichoderma stromaticum. Fitopatol. Brasil 28:408-412.
8. Bon, M. C., Bateman, R., Cilias, C., Deberdt, P., Hebbar, K. P., Hurad, C., Jones, W., Nyasse, S., Rosenquist, E., Samuels, G., Tondje, P. R., Weise, S., and Widmer, T. 2006. Highlights of an international collaborative research initiative for the biological control of the black pod disease in Cameroon. Proceedings of the 15th COPAL Meeting, San Jose, Costa Rica.

9. Bowers J. H., Bailey, B. A., Hebbar, K. P., Sanogo, S., and Lumsden, R. D. 2001. The impact of plant diseases on world chocolate production. Online. Plant Health Progress doi:10.1094/PHP-2001-0709-01-RV.

10. Brasier, C. M. and Griffith, M. J. 1979. Taxonomy of Phytophthora palmivora on cocoa. Trans. Brit. Mycol. Soc. 71:111-43.

11. Costa, J. C. B., Bezerra, J. L., and Cazorla, I. M. 1996. Controle biológico da vassoura-de-bruxa do cacueiro na Bahia com Trichoderma polysporum. Fitopatol. Brasil 21:397.

12. De Souza, J. T., Pomella, A. W. V., Bowers, J. H., Pirovani, C. P., Loguercio, L. L., and Hebbar, K. P. 2006. Genetic and biological diversity of Trichoderma stromaticum, a mycoparasite of the cacao witches'-broom pathogen. Phytopathology 96:61-67.

13. Evans, H. C. 2002. Invasive neotropical pathogens of tree crops. Pages 135-152 in: Tropical Mycology 2. Micromycetes. R. Walting, J. C. Frankland, A. M. Ainsworth, S. Issac, and C. H. Robinson, eds. CABI Publishing, Wallingford, UK.

14. Evans, H. C., Edwards, D. F., and Rodriguez, M. 1977. Research on cocoa diseases in Ecuador: Past and present. PANS 23:68-80.

15. Evans, H. C., and Prior, C. 1987. Cocoa pod diseases: Causal agents and control. Outl. Agric. 16:35-41.

16. Gotsch, N. 1997 Cocoa crop protection: An expert forecast on future progress, research priorities and policy with the help of the Delphi survey. Crop Prot. 16:227-233.

17. Griffith, G. W., Nicholson, J., Nenninger, A., Birch, R. N., and Hedger, J. N. 2003. Witches' brooms and frosty pods: Two major pathogens of cacao. N.Z. J. Bot. 41:423-435.

18. Harmen, G. E. 2000. Myths and dogmas of biocontrol. Plant Dis. 84:377393.

19. Hjorth, S., Pomella, A. W. V., Hockenhull, J., and Hebbar, P. K. 2003. Biological control of witches' broom disease, (Crinipellis perniciosa), with the co-evolved fungus, Trichoderma stromaticum: Testing different delivery regimes. Page 70 in: XIV Cocoa Conference, Accra, Ghana.

20. Holmes, K. A., Schroers, H., Thomas, S. E., Evans, H. C., and Samuels, G. J. 2004. Taxonomy and biocontrol potential of a new species of Trichoderma from the Amazon basin of South America. Mycol. Prog. 3:199210.

21. Krauss, U., and Soberanis, W. 2002. Effect of fertilization and biocontrol application frequency on cocoa pod diseases. Biol. Cont. 24:82-89.

22. Laker, H. A., and Ram, A. 1991. Investigations on integrated control of witches' broom of cocoa in Rondonia State, Brazil. Trop. Pest Manage. 38:354-358.

23. Ndoumbe-Nkeng, M., Cilas, C., Nyemb, E., Nyasse, S., Bieysse, D., Flori, A., and Sache, I. 2004. Impact of removing diseased pods on cocoa black pod caused by Phytophthora megakarya and on cocoa production in Cameroon. Crop Prot. 23:415-424.

24. Opuku, I. Y., Appiah, A. A., and Akrofi, A. Y. 2000. Phytophthora megakarya, a potential threat to the cocoa industry in Ghana. Ghana J. Agric. Sci. 33:135-142

25. Pereira, J. L. 1985. Chemical control of Phytophthora pod rot of cocoa in Brazil. Cocoa Growers Bull. 36:23-38.

26. Pereira, J. L., Almeida, L. C. C. D., and Santos, S. M. 1996. Witches' broom disease of cocoa in Bahia: Attempts at eradication and containment. Crop Prot. 15:743-752.

27. Pereira, J. L., Ram, A., Figueiredo, J. M., and Almeida, L. C. C. D. 1990. The first occurrence of witches' broom disease in the principal cocoa growing region of Brazil. Trop. Agric. 67:188-189.

28. Phillips-Mora, W., Cawich, J., Garnett, W., and Aime, M. C. 2006. First report of frosty pod rot (=moniliasis disease) caused by Moniliophthora roreri on cacao in Belize. Plant Pathol. 55:584.

29. Phillips-Mora, W., Coutino, A., Ortiz, C. F., Lopez, A. P., Hernandez, and Aime, M. C. 2006. First report of frosty pod rot (=moniliasis disease) caused by Moniliophthora roreri on cacao in Mexico. Plant Pathol. 55:584.

30. Pomella, A. W. V., De Souza, J. T., Niella, G. R., Bateman, R. P., Hebbar, K. P., Loguercio, L. L., and Lumsden, R. D. 2007. Trichoderma stromaticum for management of witches' broom in Brazil. Pages 210-217 in: Biological Control: A Global Perspective, Case Studies from Around the World. C. Vincent, M. Goettel, and G. Lazarovits, eds. CABI Publishing, Wallingford, UK.

31. Samuels, G. J., Lieckfelt, E., and Nirenberg, H. I. 1999. Trichoderma asperellum, a new species with warted conidia and redescription of $T$. viride. Sydowia 51:71-88.

32. Samuels, G. J., Pardo-Schultheiss, R., Hebbar, K. P., Lumsden, R. D., Bastos, C. N., Costa, J. C., and Bezerra, J. L. 2000. Trichoderma stromati- 
cum sp. nov. A parasite of the cacao witches' broom pathogen. Mycol. Res. 104:760-764.

33. Samuels, G. J., Suarez, C., Solis, K., Holmes, K., Thomas, S., Ismaiel, A., and Evans, H. 2006. Trichoderma theobromicola and T. paucisporum: Two new species isolated from cacao in South America. Mycol. Res. 110:381-392.

34. Sanogo, S., Pomella, A. W. V., Hebbar, P. K., Bailey, B., Costa, J. C. B., Samuels, G. J., and Lumsden, R. D. 2002. Production and germination of conidia of Trichoderma stromaticum, a mycoparasite of Crinipellis perniciosa on cacao. Phytopathology 92:1032-1037.
35. Schnell, R. J., Kuhn, D. N., Brown, J. S., Olano, C. T., Phillips-Mora, W., Amores, F. M., and Motamayor, J. C. 2007. Development of a marker assisted selection program for cacao. Phytopathology 97:1664-1669.

36. Tondje, P. R., Mbarga, J. B., Antangan, J. B., Tchana, T., Begoude, D., Nyemb, E., Deberdt, P., Bon, M. C., Samuels, G., Hebbar, K. P., and Fontem, D. 2006. Evaluation of Trichoderma asperellum (PR10, PR11, PR12, 659-7) as biological control agents of Phytophthora megakarya, the causative agent of black pod disease on cacao (Theobroma cacao). Proceedings of the 15th COPAL Meeting, San Jose, Costa Rica. 